\title{
MOC SŁABOŚCI W OBLICZU KATASTROFY. MESJAŃSKIE POPRAWKI WALTERA BENJAMINA, GIANNIEGO VATTIMO I HAROLDA BLOOMA
}

\author{
KATARZYNA SZAFRANOWSKA
}

\begin{abstract}
Abstrakt: Artykuł stanowi propozycję wykorzystania interpretacyjnych narzędzi żydowskiego mesjanizmu w celu osłabienia dyskursu umacniających się na Zachodzie narodowych populizmów. Zawiera analizę oryginalnej koncepcji słabego mesjanizmu Waltera Benjamina, jej ponownego odczytania przez Gianniego Vattimo oraz pozornie polemicznej propozycji Harolda Blooma, która słabości Benjaminowskiego mesjasza zdaje się przeciwstawiać siłę mocnego poety. Nacisk położony zostaje na reinterpretacyjne otwarcie zawarte w teoriach Benjamina, Vattimo i Blooma, pozwalające znaleźć odpowiedź na wpisane w narodowy populizm triumf i powrót mitu. Słaby mesjanizm jest przedstawiony jako interpretacyjna forma oporu przed zawłaszczeniem historii i próba jej domknięcia. W katastrofalnej kondycji współczesności można bowiem upatrywać szansy na otwarcie przed słabą myślą możliwości skutecznego rozmontowania struktur mitu.
\end{abstract}

Słowa kluczowe: narodowy populizm, słaby mesjanizm, Walter Benjamin, Harold Bloom, Gianni Vattimo, dyskurs polityczny. 
We współczesnej polityce międzynarodowej coraz bardziej widoczna jest obecność retoryki siły i dominacji. Można ją zauważyć w uporczywym podkreślaniu własnego pierwszeństwa, w potrzebie rewidowania historii i nawoływaniu do odzyskania utraconej wielkości. Przekonaniu o konieczności „wstania z kolan” (np. Karnowski 2015) towarzyszy dążenie do specyficznie rozumianej prawdy. Prawda ta jest niewatpliwie i bezkompromisowo prawda obecnych zwycięzców, która ma prowadzić m.in. do „przyszłości patriotyzmu, dostatku i dumy" (Trump 2018).

Do dyskursu politycznego powracają jednocześnie wątki myślenia apokaliptycznego. Widmo końca liberalnej demokracji, znaczne osłabienie instytucji międzynarodowych, skala kryzysu humanitarnego i klęsk żywiołowych, groźba konfliktu zbrojnego na skalę światową czy globalnej epidemii - wszystko to sprawia, że można patrzeć na współczesność przez pryzmat nadciagającej katastrofy. Apokaliptyczny język, w którym jak refren powtarzaja się takie sformułowania, jak „klęska cywilizacyjna” (Orbán 2016) czy „upadek naszej cywilizacji” (Kaczyński 2015b), chętnie wykorzystywany jest przez populistycznych polityków. Przekonanie o nadciagającej katastrofie do tego stopnia nie podlega wattpliwości, że język ten wkradł się nawet do raportu Międzyrządowego Zespołu do spraw Zmian Klimatu przy ONZ z października 2018 r. Mowa jest w nim m.in. o tragicznych skutkach globalnego ocieplenia, które odczuje przyszłe pokolenie (IPCC 2018, 2.77).

Pojawiająca się w dyskursie publicznym katastrofa stanowi punkt wyjścia dla mojej analizy. Chciałabym pokazać za jej pomoca, w jaki sposób umacniający się na Zachodzie narodowy populizm może zostać osłabiony przez interpretacyjne narzędzia żydowskiego mesjanizmu. Skupię się zwłaszcza na oryginalnej koncepcji słabego mesjanizmu Waltera Benjamina, jej ponownym odczytaniu przez Gianniego Vattimo oraz pozornie polemicznej propozycji Harolda Blooma, która słabości Benjaminowskiego mesjasza zdaje się przeciwstawiać siłę mocnego poety. W teoriach Benjamina, Vattimo i Blooma interesuje mnie przede wszystkim to, co można nazwać „drobna poprawka” - pewne reinterpretacyjne otwarcie, dzięki któremu można znaleźć odpowiedź na wpisane w populizm triumf i powrót mitu. Przedstawiając słaby mesjanizm jako interpretacyjną formę oporu przed zawłaszczeniem historii i próbą jej domknięcia, a więc przed historyczną narracją zwycięzców, postaram się wykazać, że katastrofalna kondycja współczesności otwiera przed słabą myślą możliwość skutecznego rozmontowania struktur mitu, a tym samym uniknięcia pułapek populizmu. 


\section{„Zwycięska historia” narodowych populistów}

W pierwszym ruchu chciałabym przyjrzeć się bliżej konsekwencjom wynikającym z coraz znaczniejszej obecności populizmu w debacie politycznej, w czym widzieć można rezultat załamania się dotychczasowego porządku politycznego: osłabienie hegemonii neoliberalnej (Mouffe 2018, 1-7), a nawet to, co określilibyśmy jako „globalny kryzys polityczny” (Fraser 2017, 47). Skutkami tego kryzysu są z jednej strony demokratyczny paraliż charakterystyczny dla postpolityki, a z drugiej - zwiększająca się popularność propozycji populistycznych. Nie musi się z tym jednak z konieczności wiązać niebezpieczeństwo osłabienia struktur politycznych, jak zdaje się uważać część badaczy (np. Müller 2017) traktujących populizm wyłącznie jako demokratyczną aberrację. Wyjątkowo celne wydaje mi się rozumienie populizmu jako terminu neutralnego (Fraser 2017, Mouffe 2018, Stavrakakis 2017), czerpiącego z repertuaru określonych narzędzi politycznych, a przede wszystkim oznaczającego bardziej angażujący - jako że opierający się na afektach i doświadczeniu rodzaj polityki.

W tak zarysowanych ramach można mówić o dwóch rywalizujących ze sobą populizmach. Nancy Fraser, koncentrując się na reprezentowanych wartościach, pisze o progresywnym populizmie i populizmie reakcyjnym (Fraser 2017, 56). Chantal Mouffe wyróżnia z kolei populizm prawicowy i lewicowy (Mouffe 2018, 22), a Yannis Stavrakakis populizm włączający i wyłączający, które na dwa sposoby definiuja pojęcie ludu (the people). W populizmie włączającym lud funkcjonuje jako płynny desygnat o nieostrym zakresie, podczas gdy w przypadku populizmu wyłączającego pojęcie to odnosi się do sztywno określonej, choć fantazmatycznej kategorii, takiej jak naród lub rasa. Oba populizmy mapuja przestrzeń społeczną za pomocą dychotomii „my/oni”. Pierwszy dokonuje tego, rysując podział wertykalnie, pomiędzy klasami niższymi i wyższymi, a drugi - horyzontalnie, pomiędzy tym, co wewnątrz i na zewnątrz (Stavrakakis 2017, 530).

W mojej analizie zajmę się przede wszystkim populizmem narodowym, a więc wyłączającym, który wertykalnie wytycza granicę „my/oni” za pomocą wykluczenia poza ramy tego, co narodowe, własne i prawdziwe, kolejnych grup (m.in. Żydów, imigrantów czy osób LGBTQ). W tym przypadku w pełni zgadzam się z Janem-Wernerem Müllerem, że język narodowego populizmu psuje demokrację (Müller 2017, 89). Pisząc o demokracji i czyhającym na nią zagrożeniu, mam na myśli przede wszystkim takie wartości, jak uznanie 
dla pluralizmu społecznego i rozpoznanie w nim warunku sine qua non jej funkcjonowania. Moje rozumienie demokracji bliskie jest więc koncepcji Mouffe, która podkreśla nie tylko niemożliwą do zredukowania wielość, ale również agonistyczne zmaganie różnych koncepcji i interesów. Nie chodzi więc o wytworzenie takiej rzeczywistości politycznej, w której nie byłoby miejsca na konflikt, ale o przemyślenie konfliktu jako takiego - zamianę politycznej wojny na polityczną rywalizację (Mouffe 2005, 108-116).

Narodowi populiści redukują demokratyczny lud występujący „wyłącznie jako mnogość" (Habermas 2005, 527) do wizji jednorodnego narodu afirmującego te same wartości, tę samą tradycję i historię. Dlatego też Müller - formułując swoją wąską definicję populizmu, która celnie oddaje charakter tego, co nazywam populizmem narodowym określa jego istotę jako „umoralnioną formę antypluralizmu” (Müller 2017, 41). Zauważa, że władza populistyczna zgłasza pretensje do mandatu imperatywnego, zastępującego dotychczasowy mandat wolny (Müller 2017, 55-56). Zamiast możliwości popełnienia błędu i związanej z tym odpowiedzialności, wpisanych w mandat wolny, pojawia się więc mocne przekonanie o tym, że wszystkie decyzje populistów są a priori dobre i sprawiedliwe, a ich słuszność wynika niejako z otrzymanej przez populistów władzy. Wiąże się ona z synekdochicznie rozumiana idea reprezentacji, w której poglądy i wartości populistów precyzyjnie odzwierciedlaja poglądy i wartości reprezentowanej przez nich grupy. Grupa ta jest zdaniem populistów „prawdziwy naród”, z samej definicji przeciwstawiony temu, co „sztuczne” czy „fałszywe”. Wpisanie moralnej konieczności w politykę z założenia uniemożliwia jakąkolwiek różnicę zdań, gdyż umieszcza rację niezmiennie po stronie rządzących. „Zawsze silni, zawsze niezależni, zawsze słuszni” (Trump 2018) - w tych słowach wygłoszonych przez Donalda Trumpa podczas siedemdziesiątego trzeciego zjazdu ONZ najtrafniej streszcza się istota narodowego populizmu.

Konsekwencją tego typu populistycznego „roszczenia do wyłącznego reprezentowania prawdziwego narodu”, o którym pisze Müller (2017, 7), jest także wyłączność określonej - „prawdziwej” - wizji historii, a co za tym idzie: jej jednoznaczność. Za jednorodna wizją narodu podąża więc jednoznaczny obraz historii, na przykład „Zwycięskiej historii Polski” (Źaryn 2013) czy „prawdziwej polskiej historii z prawidłowo rozłożonymi w niej akcentami” (Duda 2017). Staje się ona dla prawicowych populistów jednym z argumentów na rzecz legitymizacji własnej władzy, a przede wszystkim legitymizacji własnych działań i słów. Odpowiednio opowiedziana przeszłość - „historia wielkich zasług” 
(Duda 2017) czy „historia sprzeciwu wobec zła” (Morawiecki 2017) - wykorzystywana jest jako narzędzie do rozbudzania wyobraźni i poruszania sumień. Müller zwraca uwage na nadanie praktyce interpretacyjnej ciężaru etycznego (Müller 2017, 17). Populistyczne roszczenie do wyłącznej reprezentacji ma charakter moralny, towarzyszy jej dążenie do prawdy - dotarcie do prawdziwej wizji historii, nadanie prawdziwego kształtu narodowi itp. a co tym idzie, do osiagnięcia moralnej czystości. W populistycznej optyce wszystko to, co odmienne, osłabia narodową jedność i jako takie stoi na drodze do odzyskania utraconej wielkości. W rezultacie zostaje więc wskazane jako to, co przeciwne narodowi - jak na przykład niezmiernie groźny „wewnętrzny antypolonizm” (Kaczyński 2014) - a przede wszystkim moralnie nieczyste, o czym świadczą określenia „najgorszy sort” (Kaczyński 2015c) czy „zdradzieckie mordy” (Kaczyński 2017).

Narodowy populista operujący „moralizującą wyobraźnią polityczną” (Müller 2017, 40) posługuje się specyficznym rodzajem języka, który w dużej mierze stanowi odpowiedź na wpisany w demokrację kryzys reprezentacji. Kryzys ten polega na niemożliwej do zniesienia nieodpowiedniości pomiędzy wielością wykluczających się interesów społecznych a działaniami władzy mogącej reprezentować jedynie część z nich (Müller 2017, 106-108). W optyce populistycznej wielość ta zostaje zastapiona pozorem jedności, a pytanie odpowiedzią, co wydaje się nadawać populistycznej polityce pewną przewagę. Populizm narodowy kładzie dodatkowy nacisk na moralność i tradycję, które w dużym stopniu są wynikiem działania interpretacyjnego nadającego przeszłości pożądany przez populistów kształt. Próba uzupełnienia tego obrazu przeszłości o niuanse i niejednoznaczności zdaje się nie przynosić zamierzonego efektu, prowadząc jedynie do powstawania równoległych opowieści. To dodatkowo pogłębia podziały tworzone przez prawicowych populistów. Przykładem tego są: zaproponowane przez administrację Trumpa pojęcie ,alternatywnych faktów” (Conway 2017), upowszechnienie deprecjonującego określenia „sfingowane newsy” (fake news) czy utworzenie analogicznego pojęcia „sfingowanej narracji historycznej” (fake bistory; Netanjahu 2017).

Wyjście z impasu paralelności historycznych narracji wydaje się możliwe jedynie poprzez zmierzenie się z populistami na poziomie symbolicznym.

Jedną z odpowiedzi na zyskujący na popularności narodowy populizm może być sformułowanie politycznej kontrpropozycji, którą Mouffe określa mianem lewicowego populizmu (Mouffe 2018, 15-24). Celem lewicowego populizmu byłoby stworzenie 
zbiorowego podmiotu politycznego i skierowanie jego politycznych dążeń w stronę równości i sprawiedliwości społecznej. Takie rozegranie populizmu przeciw populizmowi, wykorzystujące część narzędzi populistycznych - odwołanie do afektów i doświadczenia, mobilizacje społeczna, wzrost zaangażowania, a co za tym idzie: aktywności politycznej dawałoby szansę na to, by zapobiec erozji pluralistycznego rozumienia demokracji. „Wszystko rozbija się o dyskursywny i afektywny rejestr, za pomocą którego znaczenie zostanie przypisane wielości demokratycznych postulatów właściwych dla obecnego »czasu populistów«”, zauważa Mouffe (2018, 79). Stawka „czasu populistów” jest więc to, w jaki sposób zostanie wyartykułowany opór wobec kryzysu politycznego i jak będzie wyglądać rzeczywistość polityczna stworzona wokół ukonstytuowanego na nowo podmiotu zbiorowego działania. Coraz pilniejsza staje się potrzeba znalezienia linii interpretacyjnej, która stanowiłaby formę oporu wobec rosnącej popularności narodowego populizmu.

W dalszej części artykułu dowiodę, że słaby mesjanizm może stanowić remedium na populistyczną retorykę siły i że tym samym przez znalezienie odmiennego języka oraz zaproponowanie radykalnie innej koncepcji historii otwiera on możliwość wyjścia z prawicowopopulistycznego impasu.

\section{Walter Benjamin i „tygrysi skok w przeszłość”}

Na początku chciałabym bliżej przyjrzeć się Benjaminowskiej koncepcji słabego mesjanizmu, przedstawionej w klasycznym tekście O pojeciu historii (w Polsce częściej nazywanym Tezami o filozofii historii), który obrósł w niezwykle ważne, niemal kanoniczne już odczytania (m.in. Agamben 2005, Derrida 1994). Nie pomijając toczącej się wokól Tez dyskusji, chciałabym spojrzeć na Benjaminowska propozycję z perspektywy żydowskiego mesjanizmu. W mojej lekturze, osadzającej tekst Benjamina w kontekście filozofii Franza Rosenzweiga i badanej przez Gershoma Scholema kabały, a więc skierowanej w stronę istotnych dla Benjamina żydowskich inspiracji, skupię się na wymiarze teologicznym tej propozycji i jej potencjalnych politycznych konsekwencjach. W teologicznym zorientowaniu tej lektury nie chodzi bynajmniej o oderwanie Benjamina od ważnej dla niego metody materializmu historycznego, o której wprost pisał w listach do Maksa Rychnera czy Gershoma Scholema (Benjamin [1910-1940] 1994, 300-301, 372-373, 377, 380), ale o dokładniejszą analizę wypracowanej 
przez niego koncepcji czasu. Twierdzę, że jest to kluczowe dla takiej wizji Benjaminowskiego mesjanizmu, która mogłaby stać się interpretacyjną linią oporu wobec mitycznego rozumienia historii.

We Fragmencie teologiczno-politycznym, wcześniejszym o dwadzieścia lat od Tez o filozofii bistorii Benjamin formułuje jeden z celów swojej filozofii. Chodzi mianowicie o „mistyczne ujęcie historii" (Benjamin [1920-1921] 2012, 95). W Benjaminowskiej filozofii wielokrotnie powraca myślenie o historii w kontekście teologicznym. W liście z 1931 r. do Rychnera Benjamin tłumaczy zalety wybranej przez siebie metody materializmu dialektycznego, jednocześnie podkreślając, że nigdy nie był w stanie myśleć w inny sposób niż teologicznie (Benjamin [1910-1940] 1994, 372). Splecenie historii z teologia - ukrytym pod stołem garbatym karłem z paraboli otwierającej Tezyy, który mistrzowsko szachuje swoich przeciwników - przenosi eschatologiczny akcent z przyszłości na przeszłość. Najdobitniej widać to w dziewiątej tezie, w której Benjaminowski anioł historii odwraca się plecami do przyszłości i patrzy na piętrzące się gruzy przeszłości (Benjamin [1940] 2012, 316). W Benjaminowskim zorientowaniu na to, co minione, można dostrzec fiksację na konieczności pozostania niezapomnianym, na co zwraca uwage Giorgio Agamben (2005, 40). To właśnie w akt zapominania wpisana jest katastrofa grożąca unicestwieniem wszystkiego, czego nie udało się zachować. Uczestnicząc w historii, stajemy się niejako współwinnymi tej katastrofy, ponieważ na wszystkich z nas odciska się piętno tego, co zapomniane. Benjaminowska historia otwarta jest jednak na odkupienie. To ona, postrzegana tutaj jako czas ujęty w materii języka, stanowi pole działania dla słabego mesjanizmu.

Benjamin pisze o „słabej mesjańskiej sile, do której przeszłość zgłasza roszczenia”, w drugiej tezie o historii (Benjamin [1940] 2012, 312). „Słaba mesjańska siła” jest zawarta w teraźniejszości możliwością odkupienia przeszłości. W teraźniejszości bowiem skrywa się możliwość „oddziaływania wstecz na czasy minione” (Benjamin [1940] 2012, 313) i nie chodzi tu wyłącznie o krytyczne odniesienie do przeszłości, ale o realną zmianę, którą może wprowadzić działanie mesjańskie. Każdy moment kryje w sobie rewolucyjny potencjał wynikający z dialektycznego napięcia pomiędzy teraźniejszością a przeszłością - wyłania się z tego mesjański sens działania politycznego. Benjamin nazywa tę zmianę „najbardziej niepozorną ze wszystkich zmian” (Benjamin [1940] 2012, 313), mimo że to od niej faktycznie zależy zbawienie historii. 
„Najbardziej niepozorna ze wszystkich zmian” z Tez o filozofii historii wydaje się niczym innym, jak „drobną poprawką”, o której Benjamin wspomina w tekście poświęconym Franzowi Kafce (Benjamin [1934] 2012, 251) - zapożyczoną od Scholema pozornie niewielką korektą rzeczywistości, na skutek której wszystko zostanie nieznacznie przesunięte, tak aby znaleźć się z powrotem na swoim miejscu. W rezultacie „wszystko będzie tak samo, jak tutaj, ale troszkę inaczej” (Scholem [1931-1938] 2006, 307). Nie wchodząc głębiej w toczący się pomiędzy Benjaminem a Scholemem spór o język materializmu historycznego (Benjamin [1910-1940] 1994, 375-380), warto przywołać badaną przez Scholema kabałę luriańską i spojrzeć na gruzy obserwowane przez anioła historii przez pryzmat kabalistycznej katastrofy, a na Benjaminowską drobna poprawkę jako na świecki wariant aktu tikkeun.

W koncepcji Izaaka Lurii katastrofa jest silnie związana z samym aktem stworzenia, stworzenie musi być bowiem niedoskonałe, aby w swej istocie różnić się od Boga - być czymś innym niż doskonały Bóg. Niedoskonałość wpisana w stworzenie wynika z tego, że wszystko w świecie jest nie do końca na swoim miejscu. Stworzenie zapoczątkowuje samowygnanie Boga w akcie cimcum. Cimcum staje się jedyną możliwością dla świata, a jednocześnie największą ofiarą i najgłębszą formą samowypędzenia. Samowygnanie i rozbicie Boga odbija się we wszelkiej istniejącej w świecie niedoskonałości. Upadek i wypędzenie Szechiny, szewirat ha-kelim, czyli rozproszenie boskiego światła na skutek rozbicia „wielkiej duszy” Adama Kadmona, wygnanie rajskiego Adama z ogrodu Eden wszystko to powtarza i pogłębia wpisaną w stworzenie katastrofę. Scholem podkreśla, że „wszystko jest jakoś rozbite, wszystko ma jakąs skazę, wszystko jest niedokończone” (Scholem [1965] 1996, 124-125). Nic już nie znajduje się tam, gdzie być powinno, a byt, który nie zajmuje swojego miejsca w hierarchii wszechświata, staje się bytem na wygnaniu. Każde wygnanie wpisuje się w akt wewnętrznego rozpadu boskiej istoty, każdy błąd i grzech to powtórzenie i kontynuacja pierwotnego rozbicia, każdy dobry uczynek o krok przybliża powrót harmonijnej jedności (Scholem [1965] 1996, 127-128). Przesycona gnostyckim dramatem niepowodzenia i odnowy kabała luriańska przesuwa akcent z jednorazowego aktu zbawienia na ciagły proces naprawy. Luriańskie tikkun ba-olam, czyli naprawa świata, dążenie do usunięcia ze świata pierwotnej skazy powstałej na skutek „rozbicia naczyń”, nadaje znaczenie każdemu nawet najdrobniejszemu działaniu. Zbawienie polega bowiem na „przywróceniu wszystkich rzeczy na właściwe miejsce” (Scholem [1973] 2006, 360), 
przy czym każdy ludzki gest w jakiś sposób kontynuuje historię stworzenia: albo pogłębiając istniejący chaos, albo przyczyniając się do naprawy tego, co pęknięte.

Między innymi właśnie z powodu właściwej dla siebie kabalistycznej perspektywy Scholem skłania się ku odczytaniu koncepcji Benjamina jako „melancholijnej, wręcz rozpaczliwej wizji historii" (Scholem [1983] 2006, 262). Sprowadza tym samym myśl Benjamina do wizji gnostyckiego świata rozbitych skorup, świata wymagającego zbawienia. Kontrowersyjność interpretacji Scholema polega głównie na tym, że wprost podaje on w wątpliwość wybrany przez autora Tez język materializmu dialektycznego. Odrzucając listowne wyjaśnienia Benjamina, który podkreślał, że materializm dialektyczny pozwala lepiej zrozumieć moment historyczny jako moment działania (Benjamin [1910-1940] 1994, 300301), Scholem traktuje go jedynie jako wymuszoną maskę, skrywającą o wiele subtelniejszą treść (Benjamin [1910-1940] 1994, 374). Jeśli nie przyjmiemy w pełni Scholemowskiej interpretacji, ale zgodzimy się z tym, że kabalistyczne odniesienia mogły stanowić jedną z inspiracji Benjamina, możemy spojrzeć na proponowane przez niego działanie mesjańskie jako na wariację na temat aktu tikk.kun, w którym odkupienie świata nie wiąże się z nadejściem mesjasza - i tym samym odsunięte jest w nieokreśloną przyszłość - ale z tym, co można zrobić tu i teraz. W Tezach miejsce mesjasza jest bowiem puste, a zadanie zbawienia świata należy do polityki. Nie jest to jednak polityka mesjańska. Skoro bowiem nie ma szans na nadejście mesjasza, oczekiwanie na odkupienie nigdy nie zostanie spełnione. Mesjańska nadzieja orientuje się więc w kierunku teraźniejszości, a polem jej działań jest sfera profanum.

Ponieważ słaby mesjanizm odnosi się do nieredukowalnej inności wydarzenia dziejącego się tu i teraz, Jacques Derrida czyta koncepcję Benjamina w kategoriach ateistycznych jako przykład „mesjanizmu bez mesjasza” opierającego się na idei sprawiedliwości (Derrida 1994, 227-228). Tym samym Derrida wycofuje mesjanizm z czysto teologicznej interpretacji, zastępując ją widmową logiką dziedzictwa i następstwa pokoleń. „Przebywanie wśród widm stanowiłoby formę polityki pamięci”, proponuje Derrida w Widmach Marksa (Derrida 1994, xviii). Derridiański „mesjanizm bez religii, mesjanizm bez mesjasza" byłby aktem sprawiedliwości wobec nieobecnych - już umarłych albo jeszcze nienarodzonych ofiar reżimu, wojen i przemocy. Mesjańska logika w tym samym stopniu byłaby więc zwrócona zarówno ku przeszłości, jak i przeszłości, funkcjonując w heterogenicznym i nieskładnym czasie. 
Pisząc o mesjańskim odkupieniu historii jako o odzyskaniu jej niezaktualizowanej widmowej potencji, Sami R. Khatib odwołuje się do kategorii tikkun (Khatib 2013b). W jego ujęciu mesjańska naprawa świata polegałaby na otwarciu możliwości tego, że przeszłość obierze inny bieg. W interpretacji Khatiba słaba mesjańska obietnica opiera się na paradoksalnej logice: wprowadza bowiem relację pomiędzy czasem historycznym a czasem mesjańskim, relację polegająca na „nieprzystępnej nieadekwatności”, faktycznie jest więc zaprzeczeniem relacji jako takiej - pozostaje „nie-relacja”. W ten sposób mesjańskość nieustannie daje świadectwo braku, istotowej niekompletności, stawiającej opór wszelkiej totalizacji. Moje postrzeganie Benjamina w dużym stopniu zbieżne jest z analizą Khatiba. Zgadzam się w pełni, że Benjaminowski słaby mesjanizm silnie wiąże się z mesjańską rekonceptualizacją czasu, a jego stawka to nietotalizujące, otwarte rozumienie historii.

Realna zmiana, która może wprowadzić działanie mesjańskie, stając się aktem sprawiedliwości wobec przeszłych i przyszłych pokoleń, możliwa jest dzięki spłaszczeniu czasu, szczelnym wypełnieniu go tym, co dzieje się teraz. Skupienie się na teraźniejszości powoduje bowiem, że „czas zatrzymuje się i zamiera w bezruchu” (Benjamin [1940] 2012, 321). W koncepcji tej czas nie przypomina już opowieści, w której wydarzenia następują po sobie jedno po drugim, ale obraz, na którym wszystko dzieje się jednocześnie. Tę znaczącą różnicę w postrzeganiu czasu można być może najzręczniej wytłumaczyć, posiłkując się przykładem protorenesansowego ujęcia czasu świętego. Różnica pomiędzy linearnym ujęciem czasu a mesjańską teraźniejszością jest analogiczna do różnicy pomiędzy narracją Ewangelii Lukasza a obrazem Siedem radości Marii Hansa Memlinga, na którym Maryja jednocześnie rodzi, rozmawia z Archaniołem Gabrielem i jest świadczynia zmartwychwstania Jezusa. Przedstawiona tu koncepcja czasu współgra z modelem czasu narodu żydowskiego ukazanym w Gwieźdżie z̧bawienia Franza Rosenzweiga, pod którego wpływem pozostawał Benjamin. Rosenzweig wyłącza naród żydowski z dziejowości historii po to, by ocalić go przed „wojenną czasowością, nieuchronnością tego, że to, co żyje, musi umrzeć (Rosenzweig [1921] 2012, 519-521). Dzięki swojemu wyobcowaniu z tego, co naznaczone czasowością w braku relacji, powodujacym, że wspólnota ta jest „narodem jedynym” - naród żydowski może istnieć poza biegiem czasu, w „wiecznej chwili”, w której tak samo obecne jest zarazem to, co jest, jak i to, co było i będzie - „pomiędzy nie wzrastająca już przeszłością i nieporuszona przyszłością" (Rosenzweig [1921] 2012, 473-479). Czas przestaje więc płynąć, a to, co przeszłe, i to, co przyszłe, zbiega się w „niezmiennej teraźniejszości”. „Niezmienna 
teraźniejszość”, ów czas uświęcony, przypomina pomimo pewnych znaczących różnic pełnię mesjańskiego Teraz, o której wspomina Benjamin. Celem pierwszej jest ocalenie przed logika przemijania, celem drugiego - ocalenie przed mityczną logiką powtórzenia.

Benjamin postrzega historię nie jako łańcuch wydarzeń umieszczonych w jednorodnym i pustym czasie, lecz jako „czas wypełniony Teraz” (Benjamin [1940] 2012, 320). W tak rozumianej płaskiej teraźniejszości ukryte są zarówno pozostałości tego, co było, jak i zalążki tego, co będzie. Błędem byłoby jednak twierdzenie, że teraźniejszość w sposób konieczny wynika z przeszłości; tak samo błędne byłoby twierdzenie, że przeszłość pomaga zrozumieć teraźniejszość. Przyjęcie modelu czasu opartego o Teraz pomaga wyjść poza tego typu linearne wynikanie. Związki pomiędzy przeszłością a teraźniejszością mają charakter „piorunowych błysków”, nie przypominają łańcuchów logicznych powiązań, ale nieciągłe, związane ze sobą dialektycznie obrazy (Benjamin [1924-1940] 2005, 508). Pojawiające się pomiędzy punktami w polu czasu konstelacje odsłaniają okruchy czasu mesjańskiego, za którymi kryje się sens. Obrazy dialektyczne to te momenty, kiedy przeszłość i teraźniejszość łączą się w przeróżne konstelacje: dzięki nim teraźniejszość pozwala odkryć na nowo sens przeszłości, a przeszłość zyskuje tym samym znaczenie i odkupienie. W obrazach dialektycznych powracaja widmowo przegrani obecnej historii wołający o akt sprawiedliwości wobec zaznanej przez nich krzywdy. Wydaje się, że tego rodzaju odkupienie historii możliwe jest wyłącznie za pomocą, „zbiorowego podmiotu zaangażowanego politycznie w momencie historycznego kryzysu" (Khatib 2013a, 84). Taka lektura byłaby spójna z pozostawionymi przez Benjamina notatkami do Tez, w których pisze on, że Marksistowska koncepcja społeczeństwa bezklasowego stanowi zsekularyzowane pojęcie czasu mesjańskiego (Benjamin [1940] 2006, 401).

Z jednej strony mielibyśmy więc do czynienia z koniecznością pojawienia się słabego mesjańskiego podmiotu politycznego, a z drugiej z nieobecnością mesjasza, który zawsze przychodzi dzień po swoim przyjściu (Kafka [1902-1923] 1961, 81). W ten sposób mesjański potencjał odkupienia przeszłości zyskiwałaby sama koncepcja czasu. Zauważa to Agamben w swojej analizie mesjanizmu Benjamina, skupiając się właśnie na tej perspektywie. Analizuje on tekst Benjamina jako konstelacje cytatów pozbawionych cudzysłowów i kreśli paralele pomiędzy Listem do Rzymian a Tezami. Postrzega je jako „dwa fundamentalne dla naszej tradycji mesjańskie teksty oddzielone prawie dwoma tysiącami lat, oba pisane w sytuacji radykalnego kryzysu" (Agamben 2005, 145). Zarówno w ujęciu świętego Pawła, jak 
i Benjamina czas mesjański znosi podział między tym, co przeszłe, a tym, co teraźniejsze, wprowadzając kolejną jakość - sferę nierozstrzygalności, w której przeszłość zostaje przesunięta w teraźniejszość, a teraźniejszość rozciaga się na przeszłość (Agamben 2005, 74). Khatib za kluczowe uważa tutaj nie samo ujęcie czasu mesjańskiego, ale napięcie pomiędzy czasem historycznym a czasem mesjańskim, które umożliwia otwarcie historii. Czas mesjański jest nielinearny, spłaszczony i zagęszczony, a-synchroniczny i a-diachroniczny. Dzięki niemu przeszłość zostaje politycznie zrekapitulowana w teraźniejszości, a „historia istnieje jedynie w nieciągłości” (Khatib 2013a, 99). Tym samym czas mesjański przeciwstawia się czasowi pustemu, czasowi określonego celu i końca.

Benjamin zakłada, że działanie mesjańskie przejawia się w wyswobadzającym przeobrażeniu historii, w uwolnieniu jej z ram mitu. W notatkach do Tez zauważa, że uwolniona od ciężaru pustego czasu historia mogłaby ukazać w pełni destrukcyjną energię wpisaną w historyczny materializm (Benjamin [1940] 2006, 406), a tym samym być może naruszyć mityczny charakter świata. Mit w ujęciu Benjamina to duszny, immanentny ład, źródło przemocy i opresji, wina wymuszona przez prawo i los. W wychodzącym od Arystotelejskiej definicji tragedii greckiej tekście Los $i$ charakter (Benjamin [1919] 2012), w którym najwyraźniej widać Benjaminowskie rozumienie mitu, Benjamin wiąże mityczność ze zniewoleniem $\mathrm{i}$ wina, a przede wszystkim rozszerza to pojęcie na deterministyczne domknięcie świata, na - jak celnie określa to Agata Bielik-Robson - „mityczna jedność świata bez pytań” (Bielik-Robson 2008, 485). Zasadą organizująca mityczny świat jest kara, zawsze uprzednia wobec tych, którzy na nią zasłużyli (Benjamin [1940] 2006, 403). Zdaniem Benjamina mit opiera się na prawie, w które zawsze wpisana jest przemoc. Nazywa on wszelką mityczną przemoc „nikczemną”, zarówno tę ustanawiająca, jak i tę podtrzymującą prawo (Benjamin [1921] 2012, 87-90); ostrze jego krytyki wymierzone jest więc zarówno przeciw kapitalizmowi, jak i liberalnemu państwu prawa. Mityczna przemoc polega przede wszystkim na repetycji, wiecznym powrocie tego samego. To również „przymus upodobniania się i zachowywania podobnie” (Benjamin [1933] 2012, 221). W ujęciu Benjamina mit to nieruchoma, wiecznie odtwarzająca się totalność (por. Bielik-Robson 2012, 423).

Zadaniem słabego mesjanizmu jest utrudnienie powrotu myślenia mitycznego, rozumianego jako uniemożliwiająca działanie, operująca przemocą struktura, zamknięty krag powtórzeń. Benjamin wprost pisze o tym w jednym z fragmentów Paså̇y, dotyczącym teorii 
poznania oraz postępu i zaznacza, że: „Najbardziej swoistą cechą doświadczenia dialektycznego jest rozbijanie pozoru »wiecznie tego samego«, a bodaj tylko powtarzalności whistorii. Autentyczne doświadczenie polityczne jest absolutnie wolne od tego pozoru" (Benjamin [1924-1940] 2005, 521). Wydaje się więc, że mesjańskie zadanie polega na stwarzaniu możliwości owego doświadczenia poprzez poszukiwanie nowych konstelacji, wktórych rozbłyśnie sens. Tym samym Benjaminowski mesjasz występuje przeciw jednoznacznemu, mitycznemu rozumieniu historii. Mesjasz ma za zadanie odnaleźć „chropowatości i zadziory”, w których rwie się ciąłość historii (Benjamin [1924-1940] 2005, 522). Dzięki pęknięciu czasu i rozchwianiu narracji można wznieść się ponad iluzję konieczności następowania po sobie wydarzeń. Warto jednak podkreślić, że nie chodzi tu o całkowite odrzucenie narracji jako takich. W tekście o Mikołaju Leskowie Benjamin podkreśla wagę dzielenia się doświadczeniem za pomocą opowieści (Benjamin [1936] 2007, 102). Każda z nich można bowiem czytać jako wariację na temat zmagania się z koszmarem mitu.

W monografii poświęconej Benjaminowi Adam Lipszyc zauważa, że proponowane przezeń ocalenie ma charakter silnie etyczny, ponieważ występuje „,przeciw fałszowi przekazu historycznego, który maskuje nieszczęście i wypiera niespełnienie”, a tym samym stanowi „skokowe, nieciągłe, ulotne rozbicie mitycznej immanencji” (Lipszyc 2012, 518-519). Działanie mesjańskie ma więc swój aspekt pozytywny i negatywny. Benjamin zaznacza, że „Mesjasz przychodzi wszak nie tylko jako zbawiciel; przychodzi także jako pogromca Antychrysta” (Benjamin [1940] 2012, 314). Z figura Antychrysta wiąże się bowiem zagrożenie unicestwienia historii, rozprzestrzenienia się tendencji, by źle pamiętać, a tym samym, na skutek ukrycia rozsianych w przeszłości iskier, niebezpieczeństwo niemożliwości jej odkupienia (Bielik-Robson 2000, 68). Zbieranie rozproszonych w czasie mesjańskich okruchów sensu stanowi zatem akt sprzeciwu, akt sprawiedliwości zwrócony przeciw upadłemu światu, przeciw fałszywej ciąłości i duszącemu domknięciu. Benjamin zauważa w Losie $i$ charakterže, że mit wiąże się z praktykami interpretacyjnymi i to właśnie tu trzeba szukać możliwości ucieczki przed mitycznym zagrożeniem. Mesjański „tygrysi skok w przeszłość" (Benjamin [1940] 2012, 320) ma na celu przede wszystkim działanie interpretacyjne. Jest wymierzony przeciw obecnym zwycięzcom, którzy kontrolując „historyczną artykulację przeszłości” (Benjamin [1940] 2012, 314), starają się także opanować przyszłość. Dla Benjamina, który zdaje się czerpać z kabały (por. Scholem [1971] 1991, 27), 
interpretacja jest narzędziem faktycznej zmiany rzeczywistości. Ponieważ świat utkany jest z materii języka (Benjamin [1916] 2012) - każda litera czy liczba, każde słowo stanowią skupisko boskiej energii, zawierają w sobie zarówno potencję twórcza, jak i interpretacyjnązbawienie świata zależy od operowania językiem. „Mesjańskie działanie językowe”, jak określa to Lipszyc (2012, 494), może stanowić skuteczną formę oporu właśnie dzięki temu, że „czesze historię pod włos” (Benjamin [1940] 2012, 315), wydobywając nowe konstelacje znaczeń w kontrze do totalnej narracyjnej reintegracji.

Mityczna interpretacja przeszłości jest nieodzowna dla retoryki narodowego populizmu. Kiedy podda się nawet pobieżnej analizie odwołania do przeszłości pojawiające się w wypowiedziach populistów, można stosunkowo łatwo dostrzec elementy mitycznego myślenia, które krytykuje Benjamin. Na przykład w wizji czasu Jarosława Kaczyńskiego silnie zaznacza się nieubłagalność konsekwencji, quasi-mityczna wina przechodząca z pokolenia na pokolenie. Dlatego też zdrajcy ojczyzny już na zawsze pozostaną zdrajcami, tak samo jak ich dzieci i wnuki. W ich DNA obecny jest bowiem „gen zdrady” (Kaczyński 2015c) - ciąży na nich wina, wyprzedzająca sam akt przewinienia. A w dodatku tak jak w rządzonej mityczną koniecznościa greckiej tragedii, „ci, którzy sa potomkami zdrajców, nigdy nie będa chcieli tego przyznać, że sa potomkami zdrajców” (Duda 2017). Prawo powtórzenia dominujące w prawicowo populistycznej wizji świata powoduje, że nie ma w nim miejsca na odkupienie i mesjańską sprawiedliwość.

Słaby mesjanizm stawia opór przede wszystkim jednoznacznej, domkniętej wizji historii. W odróżnieniu od narodowego populizmu akcentuje nie utraconą wielkość przeszłości czy nadchodząca wraz z przyszłością chwałę, ale święte Teraz. Skupienie się na teraźniejszości, które spłaszcza czas, pozwala uniknać pułapek paralelności narracji historycznych i tworzenia się kolejnych przepaści w podzielonym przez wyłączający populizm społeczeństwie. To właśnie ten eksperyment z nielinearnym postrzeganiem czasu umożliwia wyjście poza nieubłaganą logikę historii, w której kształt narracji stanowi wyłączną domenę zwycięzców, a zmarli nigdy nie są bezpieczni (Benjamin [1940] 2012, 314). Słaby mesjanizm zwraca się więc nie ku nieokreślonej przeszłości, ale ku teraźniejszości rozumianej jako pełnia czasu, obejmująca zarówno na nowo „przeczytaną” przeszłość, jak i na nowo kształtującą się dzięki temu przyszłość. Benjamin podkreśla, że „ciagłość prezentacji historycznej jest nie do urzeczywistnienia” (Benjamin [1924-1940] 2005, 518) i tym samym sprzeciwia się jednoznaczności narracji historycznej. W pełni mesjańskiego czasu wszystko dzieje się naraz 
- pośród piętrzących się gruzów rozbłyskują drobne gesty, pojedyncze akty sprawiedliwości, które tworząc konstelacje, dają szansę na odkupienie czasu. Wszystkie wyjazdy i powroty odbywają się w jednej chwili: w tym samym momencie andaluzyjscy Żydzi przybywają do Królestwa Polskiego, powstańcy listopadowi udają się na wygnanie do Paryża, a kraj opuszczają wysiedleni z Ziem Odzyskanych. Inne znaczenie wyłania się z tych wydarzeń w 1994 r., kiedy w ramach zorganizowanej akcji polskich władz do kraju przybywa dziewięćdziesięciu muzułmańskich uchodźców z Bośni, a inne w 2016 r., zaraz po zamknięciu dla czeczeńskich azylantów przejścia granicznego Terespol-Brześć. Właśnie w tej płaskiej wizji świata i wyłaniających się dzięki temu licznych konstelacjach widać wyraźnie skalę katastrofy, ale i możliwość odkupienia, naprawy, wyjścia z impasu i koła powtórzeń.

\section{„Twórcze poprawki” Gianniego Vattimo oraz Harolda Blooma}

Benjaminowska koncepcja słabego mesjanizmu dostarcza narzędzi teoretycznych do rozpracowania zagrożeń ukrytych w rzeczywistości i wymknięcia się, co starałam się pokazać, logice jednomyślności. Wątek ten kontynuuje Gianni Vattimo, wprowadzając słabe myślenie jeszcze głębiej w perspektywę społeczną. Krytykuje on monolog narodowego populizmu i identyfikuje jego główne założenia jako potrzebę powrotu do mitu, do prawdy często prawdy historycznej - rozumianej jako zgodność z pewnym mitycznym stanem rzeczy. Za Benjaminem Vattimo odnosi mit przede wszystkim do totalnej, domkniętej ideologicznie rzeczywistości (Vattimo [1983] 2012, 42). Sięgając do Benjaminowskiego O pojeciu historii, odrzuca możliwość jakiejkolwiek jednowątkowej narracji z powodu jej ideologicznego uwikłania, afirmowania kontroli i przemocy (Vattimo [1989] 1992, 2-4). Wyrastająca ze szkoły podejrzeń Vattimowska myśl słaba, odwołująca się do mnogości opowieści, stara się osłabić wpisaną w narodowy populizm pokusę prawdy absolutnej. Zamiast iluzji spójnego narracyjnie świata proponuje wielość nieciagłych obrazów reprezentujących różne punkty widzenia. Za zadanie myśli słabej Vattimo uznaje utrwalenie stanu niejasności, nieoczywistości świata, a więc działanie przeciw mitowi.

W książce Spoleczeństwo prajejryste Vattimo poddaje krytyce strategie populistyczne, które fabularyzują świat. Optując za jedną, wyłączną i domkniętą quasi-mityczną opowieścia, mieszcząca w sobie gotowe odpowiedzi na wszystkie niejasności, populiści zaostrzają spory 
iw ten sposób kształtują odpowiednie, pożądane przez nich postawy. Tę funkcję pełni na przykład opowieść o imigrantach, nasycona wojennymi metaforami, wzbudzającymi lęk i usprawiedliwiającymi użycie skrajnych środków. Opowieść ta staje się szczególnie wyrazista w czasie kampanii wyborczych. W 2015 r. Jarosław Kaczyński zyskuje głosy wyborców, insynuując, że uchodźcy wojenni przenoszą „różnego rodzaju pasożyty, pierwotniaki” (Kaczyński 2015a), traktują kościoły jak szalety i z powodu swojej „gwałtowności i agresji” stanowią zagrożenie dla sfery publicznej (Kaczyński 2015b). W 2018 r. Viktor Orbán mówi o zamknięciu granic Węgier jako o „największej bitwie, którą możemy razem stoczyć” (Orbán 2018). W jego przemówieniu wygłoszonym z okazji Węgierskiego Święta Narodowego pojawiają się nawet odniesienia do świętej wojny, która ma stanowić odpowiedź na trwającą od kilku lat ,inwazję” (Orbán 2018).

W kontrze do populistycznego „prawdziwego narodu” Vattimo proponuje kategorię społeczeństwa przejrzystego, społeczeństwa opartego na wspól-rozumieniu (Vattimo [1989] 1992, 4). Stara się przezwyciężyć mit, proponując dwie drogi odczarowania świata: za pomoca ironicznego zniekształcenia tradycji, zwłaszcza języka metafizyki, oraz otwartego zaangażowania się w etykę, a szczególnie czerpania z kategorii współczucia (pietas) i życzliwości (caritas). Vattimowskie nawiązanie do chrześcijaństwa jako do źródła tradycji hermeneutycznej, jest powrotem do religii, ale religii bez Boga, w której punktem odniesienia nie jest prawda, lecz caritas. Miłość chrześcijańska, miłość wspólnotowa staje się etycznym odniesieniem dla interpretacji. W Odpowiedrialności filozofa Vattimo wyjaśnia swoje rozumienie prawdy, określając ja jako „perswazję na rzecz zbiorowości” (Vattimo [2000] 2010, 69). Podkreśla, że odpowiedzialność za znaczenie spoczywa wyłącznie na człowieku; interpretacja rozumiana jest nie jako dominacja znaczenia, ale jako otwartość na pomyłkę i poprawkę.

Krytykując wpisaną w populizm polaryzację, Vattimo optuje za pluralizacją. Z wielości różnorakich wizji rzeczywistości wynika zdaniem autora dezorientacja, w której tkwi możliwość emancypacji. Vattimo podkreśla „emancypacyjne znaczenie »pomieszania języków«" (Vattimo [1989] 1992, 10), mające swoje źródło przede wszystkim w rozluźnieniu silnych kategorii, takich jak prawda czy konieczność. Vattimowska myśl słaba stroni więc od konieczności i jednoznaczności. Jej cele to rezygnacja z przemocy i wydobywanie ze świata istniejących heterologii, dzięki którym lepiej dostrzegalne jest pokojowe współistnienie mnogich wspólnot. Chodzi więc o polifoniczność, czyli harmonijną wielość, o ponowne przemyślenie historii po to, aby wydobyć historie słabych i zapomnianych (Vattimo [2000] 
2010, 71). W ten sposób postrzegana jest też przeszłość - jako „zespół możliwości, które zawsze otwarte są na nowe interpretacje" (Vattimo [2000] 2010, 76). Wynika z tego nieunikniona niekompletność wizji przeszłości. Według Vattimo Benjaminowski anioł historii czuje współczucie (pietas), patrząc na ruiny pod swoimi stopami (Vattimo [1983] 2012, 42). To współczucie dla wszystkiego, co mogło być, ale nigdy się nie wydarzyło.

Harold Bloom ze swoją koncepcją „lęku przed wpływem” uzupełnia obraz zmagania z mitycznością o perspektywę indywidualną. W Bloomowskiej teorii można dopatrzeć się wątków mesjańskich - czy jest to jednak mesjanizm słaby? Bloom wprost nazywa swoją teorię twórczości „mocnym pisaniem”. Jego koncepcja lęku przed wpływem to przede wszystkim dążenie do stania się „mocnym poeta”, który zdetronizuje swojego poetyckiego ojca, odwracając tym samym porządek czasu (Bloom [1973] 1997). Bloomowska teoria jest mocna także w tym sensie, że zdominowana została przez męską metaforykę. Wykorzystując niemal wyłącznie figury ojców i synów, „późnourodzonych poetów”, efebów i literackich prekursorów, Bloom idzie śladem Freuda i wskazuje ojca jako dawcę prawa i znaczenia. Jeśli skoncentrować się na wspólnym dla Blooma i Benjamina wątku kabalistycznym, da się jednak przeczytać propozycję Blooma w pewnym sensie pod włos - jako skrajnie indywidualistyczny wariant słabego mesjanizmu. Jego celem, tak jak w przypadku Benjamina, jest rozszczelnienie domkniętego świata mitu, wyrwanie się poza czas, przearanżowanie tego, co było, i nadanie biegu temu, co będzie.

Punktem wyjścia dla Blooma jest „pierwotna katastrofa”, nazywana przez niego katastrofą poetyckiego wcielenia (Bloom [1975] 2003, 5-9). Polega ona na uświadomieniu twórcy, że jego postrzeganie świata jest zapośredniczone przez język literackiego poprzednika, „mocnego pisarza”, z którego wpływem późno urodzony twórca musi się zmierzyć, jeśli chce dążyć do oryginalności. W tym ujęciu poetycki wpływ wydaje się pokrewny mitycznej konieczności, określającej, co jest możliwe, a co niemożliwe. Uświadomienie sobie własnego poetyckiego powołania, czyli powtórne narodziny poety-jakopoety, ma u Blooma ambiwalentny charakter. To zarazem nieszczęście upadku, jak i wielkie błogosławieństwo, ponieważ jedynie podczas upadku może dojść do twórczego skrętu (Bloom [1975] 2003, 18). Dążenie do oryginalności nabiera mesjanistycznego charakteru: uwalnia człowieka z okowów właściwego dla mitu powtórzenia, będącego źródłem duszącej ogólności. Stawką oryginalnej twórczości jest indywiduacja, jednostkowe ja, wyrwanie się z tego, co ogólne. Bloom wspomina w Kanonie Zachodu o ciagłym agonie między przeszłością 
a przyszłością, który ma dowieść, że dzięki sile interpretacji teraźniejszość może uzyskać prymat nad przeszłościa (Bloom [1994] 1995, 520). Potrzeba do tego kłamstwa przeciw czasowi, odwrócenia jego porządku.

Bloom przyjmuje gnostycką wizję człowieka, w której życie pojmowane jest jako ciagłe zmaganie z natura i mityczną totalnością świata. Każde istnienie jest poddane narzuconemu prawu konieczności (Bloom 1982, 8-14), a czas zdominowany jest przez przeszłość. W odróżnieniu od Benjamina, Bloom uznaje teraźniejszość za niegodną uwagi i przeklina właściwa dla współczesności kondycję opóźnienia. Wspomina o podwójnej żałobie: za przeszłością, która minęła, więc jest niemożliwa do odzyskania, i za przyszłością skazaną na przeminięcie $\mathrm{z}$ powodu wpisanej $\mathrm{w}$ nią nieistotności wynikającej $\mathrm{z}$ kondycji opóźnienia (Bloom [1973] 1997, 19). Wszystko, co istotne, zdarzyło się już w przeszłości; na teraźniejszość skazani są ci, którzy urodzili się za późno (Bloom [1989] 1991, 146). Katastrofa bycia późnourodzonym wynika z niewzruszonego przekonania, że wszystko zostało już powiedziane i że jedyne, co pozostaje, to powtórzenie. Przeszłość nawiedza teraźniejszość jak widmo. „Późny poeta” zmaga się więc z Martwymi Poetyckimi Ojcami, którzy nawiedzaja jego pisanie. Alternatywą dla późnourodzonych jest kapitulacja albo zdrada, powtórzenie albo dezinterpretacja. Silna lektura twórczości Martwego Poetyckiego Ojca stanowi wobec tego „złamanie paktu” (Bloom [1973] 1997, 95), jest „zawsze niedoczytaniem, odczytaniem z zamysłu złym” (Bloom [1975] 2003, 3). Bloomowskie mocne pisanie jest możliwe wyłącznie jako odmowa żałoby, akt oporu wobec istniejącego porządku. Dążenie do mocy odbywa się jednak przez ucieczkę, przewartościowanie własnej słabości i przedstawienie jej jako siły, unik przed koniecznością. Stawka tego zmagania to uwolnienie wyobraźni.

Autor Kabaly $i$ krytyki literackiej podkreśla związek pomiędzy kabalistyczną mistyką i twórczością (Bloom [1975] 2005). Związek ten wynika, po pierwsze, z kluczowej roli języka w myśleniu kabalistycznym, po drugie, z rewizyjnego charakteru tej tradycji, po trzecie, z zawartej tam dynamiki twórczości. W swoim modelu cyklu poetyckiego Bloom nawiązuje do kabalistycznej dialektyki stworzenia, na którą składają się upadek, twórczy akt i niedokładne powtórzenie, naprzemienność katastrofy i odkupienia. W tym odczytaniu szewirat ha-kelim nie oznacza jedynie pierwotnego upadku, grzechu wpisanego w rzeczywistość, ale podkreśla wewnętrzne powiązanie katastrofy i twórczości (Bloom [1975] 2003, 5). 
Bloomowski cykl rewizyjny obejmuje sześć kolejnych tropów, sześć rewizyjnych zwarć: clinamen, tessera, antithesis, kenosis, demonizację, askesis i apophrades. Rozpoczynające go clinamen, zapożyczone od Lukrecjusza, odnosi się do lekkiego skrętu spadających atomów, wyłomu w ściśle określonym prawie natury. Clinamen to zarazem błąd i pierwszy trop rewizyjny. Twórczy proces rozpoczyna więc Bloom od uchybienia, błędu i porażki. Według Blooma każda twórczość, a zwłaszcza poezja, polega na odchyleniu od oryginalnego znaczenia, na sprzeniewierzeniu. Demiurgiczny potencjał języka przejawia się w tworzeniu i niszczeniu finezyjnej sieci powiązań, które tworzą świat. Słowa to „twórcza poprawka” (Bloom [1973] 1997, 29). Są formą buntu przeciwko domkniętemu, określonemu kształtowi przeszłości. Uświadomienie sobie własnej kondycji zapóźnienia rozpoczyna retoryczną rebelię przeciwko porządkowi czasu. Bloomowska koncepcja wolności wynika więc z nieciagłości, polega na oporze wobec autorytetu czasu, na grze pomiędzy ciagłością a zerwaniem.

Słaby charakter propozycji mesjańskiej Blooma można dostrzec w tym, że teoria ta operuje przede wszystkim seriami uników i zwrotów, kładąc nacisk na akt interpretacyjny złożony z niedopowiedzeń i przeinaczeń. Bloomowski „mocny poeta” zyskuje swoja moc właśnie przez to, że własną słabość przedstawia jako siłę. Autor podkreśla, że poezja jest nie tylko ucieczką przed tradycją, lecz także próbą odwrócenia porządku władzy. Mocne pisanie ma na celu samowywyższenie, nazwane przez Bielik-Robson „narcystyczną bybris” (Bielik-Robson 2000, 94). Jednak ciagle pozostaje ono działaniem mesjańskim zwróconym do wewnątrz, które dopiero w swojej osobności, rozpaczy i wycofaniu znajduje impuls do rebelii przeciw zastanej rzeczywistości. We własnej jednostkowości i odosobnieniu zawsze tkwi cień winy, która jest winą wynikająca ze zdrady, sprzeniewierzenia się przeszłości, grzechu przeciw ciagłości. Pokrewny kabalistycznemu pojęciu cimcum zwrot do wewnątrz pozostaje zarówno twórczą możliwością jak i katastrofą.

Bloom okazuje się niezwykle przydatny jako interpretator katastrofy. Zauważa to Mark Fisher - w jego książce poświęconej krytyce kapitalizmu pojawia się odniesienie do Blooma. Fisher pisze tam o wkradającej się do rzeczywistości katastrofie, wynikającej z powtórzenia, z niemożliwości pojawienia się czegoś nowego, z kulturowo-społecznego zastoju. Normalizacja kryzysu nie pozwala nawet na pomyślenie o środkach umożliwiających jego zakończenie. Koniec już nastapił, a przyszłość to jedynie niekończące się powtórzenie przeszłości. W tę wizję świata ukradkiem wkrada się „nadzieja wynikająca ze słabego 
mesjanizmu, że coś nowego może się jednak pojawić” (Fisher 2009, 3). W Bloomowskim skupieniu na zwrocie, tropie, skręcie, odchyleniu chodzi o twórcze przekształcenie tego, co dane, a zarazem uniknięcie zarówno powtórzenia, jak i zerwania. To samo odwrócenie czy skręcenie obecne jest także $\mathrm{w}$ greckim słowie katastrofa ( $\dot{\eta} \varkappa \alpha \tau \alpha \sigma \tau \varrho o \varphi \dot{\eta})$ czy łacińskim subversio, przywodzącym na myśl rewolucję. Obrót, który słychać w łacińskiej revolutio, nie musi więc z konieczności oznaczać powrotu do tego samego. W możliwości wynikającej z wprawienia w ruch ukryta jest szansa na zmianę, wprowadzenie „twórczej poprawki”. Analizowany przez Blooma cykl rewizyjny kończy się zawsze rozpoczęciem nowego cyklu chodzi więc o walkę o te drobne przesunięcia, które mają miejsce podczas kolejnych zmagań z przeszłością.

Myślenie o współczesności w kategorii katastrofy nie musi oznaczać więc myślenia o upadku, ale może wiązać się z możliwością zwrotu czy przewrotu. Katastrofa jest w stanie być pomyślana wywrotowo: jako szansa na uzyskanie dystansu niezbędnego do podjęcia krytyki obecnego stanu rzeczy, możliwość przewrotu, odwrócenia czy przeinaczenia biegu dziejów. Myślenie w kategoriach katastrofy może paradoksalnie stać się myśleniem, jak to ujął w Pasażach Benjamin, „przeciwko prorokom upadku” (Benjamin [1924-1940] 2005, 505). Interpretacyjne podejście do katastrofy jest w stanie uczynić z niej rewolucyjny krok do przodu. Widziana w ten sposób katastrofa pozostaje nie tyle przekleństwem bezwładnego upadku, nad którym nie ma kontroli, ile odchyleniem - jak Bloomowsko-Lukrecjańskie clinamen - które staje się szansą na osłabienie mitu i zmianę obecnej konstelacji.

\section{Słaby mesjanizm jako możliwość politycznego otwarcia}

Zastanawiając się nad subwersywnym potencjałem katastrofy, chciałabym powrócić do przywołanego wcześniej kryzysu polityczności. Da się dostrzec w tym postpolitycznym kryzysie szansę na pogłębienie rozumienia demokracji i odzyskanie historii. W ten sposób postrzega „czas populistów” Mouffe (2018, 5): jako możliwość radykalizacji demokracji za pomocą lewicowego populizmu, który skutecznie przeciwstawiłby się wzrostowi nastrojów nacjonalistycznych. Działający transwersalnie i odwołujący się do różnorodności doświadczenia lewicowy populizm mógłby, zdaniem Mouffe, zrekonfigurować obecny 
porządek społeczny i stworzyć wokól na nowo ukonstytuowanego podmiotu zbiorowego działania odmienną od dotychczasowej rzeczywistość polityczną (Mouffe 2018, 11).

Benjaminowskie rozumienie czasu i historii byłoby według mnie zbieżne z polityczną transwersalnością proponowaną przez Mouffe, obecną w niej wielościa dążeń i celów. Położenie nacisku na różnorodność tożsamości, a co za tym idzie, różnorodność form patriotyzmu, miałoby potencjał osłabienia ujednolicającego i totalizującego dyskursu narodowego. Słaby mesjanizm zachęcałby do mnożenia mikronarracji na temat przeszłości śledzenia ich punktów zbieżnych i rozbieżności. Chodziłoby o wielość opowieści, które wyłaniają się z konstelacji historii, ale nie wykluczaja innych narracji. Wielość mikrohistorii, nie funkcjonujących jako równoległe opowieści, ale tworzących różnorodne konfiguracje, mogłaby przyczynić się do zwiększenia pluralizmu. Tak rozumiana słaba mesjańska siła nie byłaby jedynie formą inwentaryzacji różnorodnych doświadczeń i opowieści, nie skupiałaby się wyłącznie na rozpoznaniu niewykorzystanych szans na zbiorową emancypację, ale stanowiłaby przede wszystkim zobowiązanie etyczne. Wynikające z niej słabe polityczne działanie byłoby wzięciem odpowiedzialności za odkupienie przeszłych pokoleń i tym samym pozostawiałoby narrację historyczną zawsze niedokończoną i otwartą na zmiany.

W ten sposób interpretacyjna strategia słabego mesjanizmu mogłaby dać odpór narodowym populizmom. Jej stawką byłoby ocalenie demokracji. Słaba siła stanowiłaby moment zwrotny w procesie zbawczego odkupienia, służąc odzyskaniu niezrealizowanej potencjalności historii, a tym samym otwierając możliwość tego, że historia obierze odmienny bieg. Tym samym, podejmując próbę zboczenia z katastrofalnego kursu obecnej historii, mesjanizm występowałby przeciw operującej przemocą mitycznej konieczności. To przede wszystkim na płaszczyźnie politycznej słaba mesjańska siła otwierałaby drogę do pojawienia się tych możliwości, które zniknęły wraz z nabraniem przez przeszłość określonego kształtu. W ten właśnie sposób słaby mesjanizm mógłby stać się formą oporu wobec domkniętej narracji historycznej narodowego populizmu, za pomoca której populiści legitymizuja niesprawiedliwość wpisaną w czas teraźniejszy: umożliwiając myślenie o przeszłości jako otwartej na zbawienie. 


\section{Wykaz literatury}

Agamben, Giorgio. 2005. The Time That Remains. A Commentary on the Letter to the Romans.

Tłum. Patricia Dailey. Stanford: Stanford University Press.

Benjamin, Walter. [1910-1940] 1994. The Correspondence of W alter Benjamin, red. Gershom

Scholem i Theodor W. Adorno. Tłum. Manfred R. Jacobson i Evelyn M. Jacobson.

Chicago: The University of Chicago Press.

Benjamin, Walter. [1916] 2012. „O języku w ogóle i o języku człowieka.” Tłum. Adam

Lipszyc. W Konstelacje. Wybór tekstów. Kraków: Wydawnictwo Uniwersytetu

Jagiellońskiego.

Benjamin, Walter. [1919] 2012. „Los i charakter.” Tłum. Adam Lipszyc. W Konstelacje. Wybór tekstów. Kraków: Wydawnictwo Uniwersytetu Jagiellońskiego.

Benjamin, Walter. [1920-1921] 2012. „Fragment teologiczno-polityczny.” Tłum. Adam

Lipszyc. W Konstelacje. Wybór tekstów. Kraków: Wydawnictwo Uniwersytetu

Jagiellońskiego.

Benjamin, Walter. [1921] 2012. „Przyczynek do krytyki przemocy.” Tłum. Adam Lipszyc. W Konstelacje. Wybór tekstów. Kraków: Wydawnictwo Uniwersytetu Jagiellońskiego.

Benjamin, Walter. [1924-1940] 2005. Pasaże. Tłum. Ireneusz Kania. Kraków: Wydawnictwo Literackie.

Benjamin, Walter. [1933] 2012. „O zdolności mimetycznej.” Tłum. Adam Lipszyc. W Konstelacje. Wybór tekstów. Kraków: Wydawnictwo Uniwersytetu Jagiellońskiego.

Benjamin, Walter. [1934] 2012. „Franz Kafka. Z okazji dziesiątej rocznicy jego śmierci.” Tłum. Adam Lipszyc. W Konstelacje. Wybór tekstów. Kraków: Wydawnictwo Uniwersytetu Jagiellońskiego.

Benjamin, Walter. [1936] 2007. „The Storyteller. Reflections on the Works of Nikolai Leskov." Tłum. Harry Zohn. W Illuminations. Essays and Reflections, red. Hannah Arendt. New York: Schocken Books.

Benjamin, Walter. [1940] 2006. „Paralipomena to »On the Concept of History«.” Tłum.

Edmund Jephcott i Howard Eiland. W Selected Writings, vol. 4, 1938-1940, red. Howard Eiland i Michael W. Jennings. Cambridge: Harvard University Press.

Benjamin, Walter. [1940] 2012. „O pojęciu historii.” Tłum. Adam Lipszyc. W Konstelacje. Wybór tekstów. Kraków: Wydawnictwo Uniwersytetu Jagiellońskiego.

Bielik-Robson, Agata. 2000. Inna nowoczesnosć. Pytania o wspótcresna formute duchowosci. Kraków: Universitas.

Bielik-Robson, Agata. 2008. „Na pustyni.” Kryptoteologie pö̌nej nowoczesnosci. Kraków: Universitas.

Bielik-Robson, Agata. 2012. Erros. Mesjanski witalizm i filozofia. Krakow: Universitas.

Bloom, Harold. [1973] 1997. The Anxiety of Influence. A Theory of Poetry. Oxford: Oxford University Press.

Bloom, Harold. [1975] 2003. A Map of Misreading. Oxford: Oxford University Press.

Bloom, Harold. [1975] 2005. Kabbalah and Criticism. New York: Continuum.

Bloom, Harold. 1982. Agon. Towards a Theory of Revisionism. Oxford - New York - Toronto Melbourne: Oxford University Press.

Bloom, Harold. [1989] 1991. „Freud and Beyond.” W Ruin the Sacred Truths. Poetry and Belief from the Bible to the Present. Cambridge, Massachusetts - London: Harvard University Press. 
Bloom, Harold. [1994] 1995. The Western Canon. The Books and School of the Ages. New York: Riverhead Books.

Conway, Kellyanne. 2017. Wystapienie w Telewizji NBC (22 stycznia 2017). Za: NBC News, „Kellyanne Conway: Press Secretary Sean Spicer Gave »Alternative Facts«. Meet The Press. NBC News", 22 stycznia 2017. https://youtube.com/watch?v=VSrEEDQgFc8.

Derrida, Jacques. 1994. Spectres of Marx. The State of the Debt, the Work of Mourning and the New International. Tłum. Peggy Kamuf. New York - London: Routledge.

Duda, Andrzej. 2017. Wywiad dla TVP Historia (30 kwietnia 2017). Za: oficjalna strona Prezydenta Rzeczpospolitej Polskiej, „Wywiad Prezydenta RP dla TVP Historia”, 30 kwietnia 2017. http://www.prezydent.pl/aktualnosci/wypowiedzi-prezydenta$\mathrm{rp} /$ wywiady/art,104,wywiad-prezydenta-rp-dla-tvp-historia.html.

Fisher, Mark. 2009. Capitalist Realism. Is There No Alternative?. Winchester: Zero Books. Fraser, Nancy. 2017. „From Progressive Neoliberalism to Trump - and Beyond”. American Affairs 4: 46-64.

Habermas, Jürgen. 2005. Faktyczność i obowiqzywanie. Teoria dyskursu wobec zagadnień prawa $i$ demokratycznego państwa prawnego. Tłum. Adam Romaniuk i Robert Marszałek. Warszawa: Wydawnictwo Naukowe Scholar.

Intergovernmental Panel on Climate Change (IPCC). 2018. „Global Warming of $1.5^{\circ} \mathrm{C.”}$ http://www.ipcc.ch/report/sr15/.

Kaczyński, Jarosław. 2014. Przemówienie na Kongresie PiS (Przysucha, 18 stycznia 2014). Za: Prawo i Sprawiedliwość, „Przemówienie Prezesa PiS Jarosława Kaczyńskiego na Kongresie »PiS bliżej ludzi. Polska jest jedna«", 28 stycznia 2014. https://youtube.com/watch?v=-pCYBrOPiRY.

Kaczyński, Jarosław. 2015a. Przemówienie podczas spotkania wyborczego (Maków Mazowiecki, 12 października 2015). Za: Prawo i Sprawiedliwość, „Jarosław Kaczyński

— Wystapienie w Makowie Mazowieckim”, 13 października 2015. https://youtube.com/watch?v=9alU8D3RWE4.

Kaczyński, Jarosław. 2015b. Wystapienie podczas posiedzenia Sejmu VII kadencji (Warszawa, 16 września 2015). Za: Sejm Rzeczpospolitej Polskiej, „Sprawozdanie stenograficzne 100. posiedzenia Sejmu Rzeczpospolitej Polskiej w dniu 16 września 2015”, 16 września 2015.

http://orka2.sejm.gov.pl/StenoInter7.nsf/0/A8CA0F4060DE3B1CC1257EC2007228 12/\%24File/100_a_ksiazka.pdf.

Kaczyński, Jarosław. 2015c. Wystąpienie w Telewizji Republika (11 grudnia 2015). Za: Telewizja Republika, „Telewizja Republika - Jarosław Kaczyński (PiS) - W Punkt 2015-12-11", 11 grudnia 2015. https://youtube.com/watch?v=LCK_biZe_KU.

Kaczyński, Jarosław. 2017. Wystąpienie podczas posiedzenia Sejmu VIII kadencji (Warszawa, 18 lipca 2017). Za: Sejm Rzeczpospolitej Polskiej, „Sprawozdanie stenograficzne 46. posiedzenia Sejmu Rzeczpospolitej Polskiej w dniu 18 lipca 2017 (pierwszy dzień obrad)", 18 lipca 2017.

http://orka2.sejm.gov.pl/StenoInter8.nsf/0/63A8F1055153C815C1258162000F7136/ \%24File/46_a_bis_ksiazka.pdf.

Kafka, Franz. [1902-1923] 1961. Parables and Paradoxes. Tłum. Clement Geenberg, Ernst Kaiser i Eithne Wilkins, Willa i Edwin Muir, Tania i James Stern. New York: Schocken Books.

Karnowski, Jacek (red.). 2015. „Polska wstaje z kolan: Prezydent Duda podbija świat. W Sieci 40. 
Khatib, Sami R. 2013a. „A Non-Nullified Nothingness: Walter Benjamin and the Messianic.” Tłum. Richard Littlejohns. Stasis. Journal in Social and Political Theory 1: 82-108.

Khatib, Sami R. 2013b. „The Messianic Without Messianism. Walter Benjamin's Materialist Theology." Anthropology \& Materialism. A Journal of Social Research 1.

https://journals.openedition.org/am/159.

Lipszyc, Adam. 2012. Sprawiedliwość na końcu jezylka. Caytanie Waltera Benjamina. Kraków: Universitas.

Morawiecki, Mateusz. 2017. Exposé (Warszawa, 12 grudnia 2017). Za: Kancelaria Prezesa Rady Ministrów, „Exposé premiera Mateusza Morawieckiego - stenogram”, 12 grudnia 2017. https://www.premier.gov.pl/expose-premiera-mateusza-morawieckiegostenogram.html.

Mouffe, Chantal. 2005. Paradoks demokracji. Tłum. Wojciech Jach, Magdalena Kamińska i Andrzej Orzechowski. Wrocław: Wydawnictwo Naukowe Dolnośląskiej Szkoły Wyższej Edukacji TWP.

Mouffe, Chantal. 2018. For a Left Populism. London - New York: Verso.

Müller, Jan-Werner. 2017. Co to jest populizm? Tłum. Michał Sutowski. Warszawa: Wydawnictwo Krytyki Politycznej.

Netanjahu, Benjamin. 2017. Przemówienie przed Zgromadzeniem Ogólnym Organizacji Narodów Zjednoczonych (Nowy Jork, 19 września 2017). Za: Israeli Prime Minister's Office, „PM Netanyahu’s Speech at the United Nations General Assembly”, 19 września 2017.

http://www.pmo.gov.il/English/MediaCenter/Speeches/Pages/speechun190917.aspx.

Orbán, Viktor. 2016. Przemówienie w Parlamencie (Budapeszt, 12 września 2016). Za:

Website of Hungarian Government, „Prime Minister Viktor Orbán’s address in Parliament before the start of daily business", 12 września 2016.

http://www.kormany.hu/en/the-prime-minister/the-prime-minister-sspeeches/prime-minister-viktor-orban-s-address-in-parliament-before-the-start-ofdaily-business20160912.

Orbán, Viktor. 2018. Przemówienie podczas Święta Narodowego (Budapeszt, 15 marca 2018). Za: Website of Hungarian Government, „Orbán Viktor's ceremonial speech on the 170th anniversary of the Hungarian Revolution of 1848", 15 marca 2018. http://www.kormany.hu/en/the-prime-minister/the-prime-minister-sspeeches/orban-viktor-s-ceremonial-speech-on-the-170th-anniversary-of-thehungarian-revolution-of-1848.

Rosenzweig, Franz. [1921] 2012. Gwiazda zbawienia. Tłum. Tadeusz Gadacz. Warszawa: iTON Society.

Scholem, Gershom. [1931-1938] 2006. „Korespondencja Gershoma Scholema i Waltera Benjamina (wybór)." Tłum. Adam Lipszyc. W Żydz̨i i Niemcy. Eseje, listy, rożmowa. Sejny: Fundacja Pogranicze.

Scholem, Gershom. [1965] 1996. Kabała i jej symbolika. Tłum. Ryszard Wojnarowski. Kraków: Znak.

Scholem, Gershom. [1971] 1991. Judai:m. Pare głównych poję́. Tłum. Juliusz Zychowicz. Kraków: Inter Esse.

Scholem, Gershom. [1973] 2006. „Rozważania o teologii żydowskiej w naszych czasach.” Tłum. Adam Lipszyc. W Żydzi i Niemcy. Eseje, listy, rozmowa. Sejny: Fundacja Pogranicze.

Scholem, Gershom. [1983] 2006. „Walter Benjamin i jego anioł.” Tłum. Adam Lipszyc. W Żydzi i Niemcy. Eseje, listy, rożmowa. Sejny: Fundacja Pogranicze. 
Stavrakakis, Yannis. 2017. „Discourse Theory in Populism Research. Three Challenges and a Dillema." Journal of Language and Politics 4: 523-534.

Vattimo, Gianni. [1983] 2012. „Dialectics, Difference, Weak Thought.” Tłum. Peter Carravetta. W Weak Thought, red. Gianni Vattimo i Pier Aldo Rovatti. New York: Suny Press.

Vattimo, Gianni. 1987. „The End of (Hi)story”. Chicago Review 4: 20-30.

Vattimo, Gianni. [1989] 1992. The Transparent Society. Tłum. David Webb. BaltimoreMaryland: Polity Press.

Vattimo, Gianni. [2000] 2010. The Responsibility of The Philosopher. Tłum. William McCuaig. New York: Columbia University Press.

Trump, Donald. 2018. „Remarks to the 73rd Session of the United Nations General Assembly." United Nations Headquarters, New York. September 25, 2018. https://www.whitehouse.gov/briefings-statements/remarks-president-trump-73rdsession-united-nations-general-assembly-new-york-ny/.

Żaryn, Jan (red.). 2013. „Jak zwyciężaliśmy”, 16 maja 2013. https://www.wsieciprawdy.pl/sieci-historii.html. 
Katarzyna Szafranowska - filozofka, kulturoznawczyni i działaczka organizacji pozarządowych. Doktoryzowała się pracą z filozofii literatury, negocjując Gillesa Deleuze’a z Haroldem Bloomem. Od 2015 r. wykłada dwudziestowieczną filozofię żydowską w Instytucie Historycznym UW, a od 2016 r. jest członkinia Laboratorium TechnoHumanistyki Wydziału „Artes Liberales”. W swojej pracy badawczej zajmowała się m.in. filozoficzną krytyką prze-mocy, a także pojęciem gościnności. Obecnie bada wpływ myśli francuskiej na feministyczną teologię żydowską.

EMAIL: ka.szafranowska@outlook.com

Cytowanie: Szafranowska, Katarzyna. 2019. „Moc słabości w obliczu katastrofy. Mesjańskie poprawki Waltera Benjamina, Gianniego Vattimo i Harolda Blooma.” Praktyka Teoretyczna 2(32): 82-107

DOI: $10.14746 /$ prt.2019.2.5

\section{AUTHOR: Katarzyna Szafranowska}

TITLE: The power of weakness in the face of the catastrophe. The messianic adjustments of Walter Benjamin, Gianni Vattimo, and Harold Bloom

ABSTRACT: The paper proposes to use interpretative tools of Jewish messianism in order to weaken the discourse of national populisms that currently have gained strength in the political landscape of the West. It contains an analysis of the original conception of weak messianism elaborated by Walter Benjamin, its reading by Gianni Vattimo, and seemingly polemical proposition by Harold Bloom, who contrasts the weakness of Benjamin's messiah with the strength of the late poet. Examining the theories of Benjamin, Vattimo, and Bloom, it puts an emphasis on the reinterpretative opening that allows finding the answer to the triumph and return of the mythical embedded in the national populism. The paper maintains that weak messianism could be seen as an interpretative form of resistance against the populist appropriation of history, seeing in the contemporary catastrophic condition a chance for the weak thought to effectively dismantle the structures of the myth.

KEYWORDS: national populism, weak messianism, Walter Benjamin, Harold Bloom, Gianni Vattimo, political discourse 